Article

\title{
Analysis of Medium-Scale Solar Thermal Systems and Their Potential in Lithuania
}

\section{Rokas Valančius ${ }^{1}$, Andrius Jurelionis ${ }^{1, *}$, Rolandas Jonynas ${ }^{2}$, Vladislovas Katinas ${ }^{3}$ and Eugenijus Perednis ${ }^{3}$}

1 Faculty of Civil Engineering and Architecture, Kaunas University of Technology, Studentų str. 48, Kaunas LT-44029, Lithuania; E-Mail: rokas.valancius@ktu.lt

2 Faculty of Mechanical Engineering and Design, Kaunas University of Technology, Studentų str. 56, Kaunas LT-51424, Lithuania; E-Mail: rolandas.jonynas@ktu.lt

3 Laboratory of Renewable Energy, Lithuanian Energy Institute, Breslaujos str. 3, Kaunas LT-44403, Lithuania; E-Mails: res@mail.lei.lt (V.K.); saule@mail.lei.lt (E.P.)

* Author to whom correspondence should be addressed; E-Mail: andrius.jurelionis@ktu.lt; Tel.: +370-37-300-492.

Academic Editor: Chi-Ming Lai

Received: 20 March 2015 / Accepted: 4 June 2015 / Published: 16 June 2015

\begin{abstract}
Medium-scale solar hot water systems with a total solar panel area varying from 60 to $166 \mathrm{~m}^{2}$ have been installed in Lithuania since 2002. However, the performance of these systems varies depending on the type of energy users, equipment and design of the systems, as well as their maintenance. The aim of this paper was to analyse operational SHW systems from the perspective of energy production and economic benefit as well as to outline the differences of their actual performance compared to the numerical simulation results. Three different medium-scale solar thermal systems in Lithuania were selected for the analysis varying in both equipment used (flat type solar collectors, evacuated tube collectors) and type of energy user (swimming pool building, domestic hot water heating, district heating). The results of the analysis showed that in the analysed cases the gap between measured and modelled data of heat energy produced by SHW systems was approx. 11\%. From the economical perspective, the system with flat type solar collectors used for domestic hot water production was proved to be most efficient. However, calculation of Internal Rate of Return showed that a grant of $35 \%$ is required for this project to be fully profitable.
\end{abstract}


Keywords: solar heat energy; solar water heating; simulation and monitoring; energy analysis; financial analysis

\section{Introduction}

Solar water heating (SHW) is one of the most common solar thermal applications. In 2012 the world added 55.4 GWth (more than 79 million $\mathrm{m}^{2}$ ) of solar heat capacity [1]. However, the European market contracted again for the newly installed capacity in 2012, which totalled 2.14 GWth (approximately 3.05 million $\mathrm{m}^{2}$ ). This represents a decrease of $11.8 \%$ in comparison with 2012 . The total installed capacity increased by $1.75 \mathrm{GWth}$, attaining $30.2 \mathrm{GW}$ th $\left(43.1\right.$ million $\mathrm{m}^{2}$ ). It shows an increase of $6.2 \%$ on the total installed capacity at the end of 2012. The European solar thermal market stagnated in 2013. Germany, representing one third of this market, has led this decline, with a decrease of $11 \%$ compared with 2012, totalling only 714 MWth (1.02 million $\left.\mathrm{m}^{2}\right)$. Among the larger markets France experienced the strongest decrease $(-24 \%)$, while the medium size markets such as Portugal were most affected $(-31 \%)$. Overall 43.1 million $\mathrm{m}^{2}$ (30.2 GWth) of glazed solar collectors were installed till the end of 2013. Most popular types of solar collectors in EU and Switzerland are flat plate (89\%) and evacuated tube $(11 \%)$ collectors. In the slowly growing Lithuanian market only about $8200 \mathrm{~m}^{2}(5740 \mathrm{kWth})$ of glazed solar collectors were installed till the end of 2013 [2].

The market growth of solar thermal systems and photovoltaics in Europe depends on the policies of the various governments towards the use of solar energy systems, on the sensitivity of the people concerning the environment and on the improvement of the technology combined with price reduction of solar systems. Considering the renewables targets of the EU in the 20-20-20 programme, solar energy systems can play a significant role in many countries [3].

The yearly potential of solar energy yield in Lithuania is about $1000 \mathrm{kWh} / \mathrm{m}^{2}$ and the daily potential of solar energy yield onto horizontal surface varies between $0.55 \mathrm{kWh}$ in January and $5.8 \mathrm{kWh}$ in June. The techno-economic potential of solar heat energy production in the country reaches $1.5 \mathrm{TWh} / \mathrm{year}$ (129 ktoe) and almost the whole irradiated solar energy is collected during the warm period of the year (from April till October).

Research performed in Ireland revealed that in northern maritime climates well designed small solar water heating systems $\left(\sim 4 \mathrm{~m}^{2}\right)$ with a glazed flat plate collector would generate between 486 and $497 \mathrm{kWh} / \mathrm{m}^{2} /$ year of heat [4].

A study performed in Jordan where global solar energy is approximately $1800 \mathrm{kWh} / \mathrm{m}^{2} /$ year, showed that evacuated tube, blue and black coating-selective copper collectors are recommended for medium and large scale applications due to their long life-span, high efficiency and easy maintenance [5]. Aluminium collectors were recommended for residential SHW applications. The study showed that a payback period of 1.9 years can be achieved in the case when evacuated tube collectors are used for swimming pool heating.

The study in Greece showed that a small solar system consisting of a flat plate collector panel of $4 \mathrm{~m}^{2}$ and a 200 liter hot water storage tank would provide with life cycle savings equal to 4280 EUR and the pay-back time of such system in Mediterranean climate is 5 years [6]. 
On the other hand, life cycle cost analysis showed that seasonal thermal storage systems for solar thermal systems in cold climates do not result in an acceptable payback period, under the default economic conditions. However, with higher rates of inflation and with some financial incentives, the initial costs could be recovered in a shorter period of time [7].

The study performed in Scharnhauser Park, Ostfildern (Germany) showed that existing collector area can maximally contribute to $0.3 \%$ of the total heating energy demand in a district heating network [8]. However with $421 \mathrm{kWh} / \mathrm{m}^{2}$ per year specific solar gain from a return pipe into a return pipe assisted option is energetically the most effective strategy to integrate the existing solar thermal collectors into the district heating network.

Another study performed in Germany showed that solar thermal systems can be used for industrial processes and the theoretical potential of solar heat for these purposes below $300{ }^{\circ} \mathrm{C}$ in Germany accounts for $134 \mathrm{TWh}$ per year in total, the technical potential being $16 \mathrm{TWh}$ per year or $3.4 \%$ of the overall industrial heat demand [9].

District solar thermal energy applications are common in almost all Scandinavian countries. The Norwegian market for solar thermal systems seems to be relatively constant and was relatively small until 2012. In November 2012, the Norwegian power supplier launched its new 13,000 $\mathrm{m}^{2}$ solar district heating plant in the town of Lillestrøm near Oslo. The plant of $323 \mathrm{kWh} / \mathrm{m}^{2}$ of collector area delivers $4200 \mathrm{MWh}$ per year of solar heat and provides approximately $3 \%$ of the network's total heat supply [10]. The largest solar thermal system in Sweden is integrated with a district heating system located in Kungälv, Göteborg. The system is designed with $10,000 \mathrm{~m}^{2}$ flat plate collectors for a district heating network "into a return pipe" and delivers about $3500 \mathrm{MWh}$ per year as well as reduces about $1000 \mathrm{t} \mathrm{CO} /$ year. The calculated heat energy price from the solar system is $48.6 \mathrm{EUR} / \mathrm{MWh}$ (29.2 EUR/MWh with grant) [11,12].

In 2014 the World's largest solar heat plant was inaugurated in Dronninglund, Denmark. The plant consists of 2.982 solar heat panels with total area of $37.573 \mathrm{~m}^{2}$. The solar heat is delivered to the users of district heating network in Dronninglund. The surplus heat is fed into to a large water storage of $61,700 \mathrm{~m}^{3}$ and used during autumn and winter. A heat pump uses the water as its source of heat and its temperature drops down to $10{ }^{\circ} \mathrm{C}$ in winter time. Expected energy production of this plant is approximately 17.5 MWh annually or about $465 \mathrm{kWh} / \mathrm{m}^{2} /$ year $[13,14]$.

Some studies in Lithuania showed that small solar domestic hot water (DHW) systems with flat plate or evacuated tube collectors can produce from 335 to $523 \mathrm{kWh} / \mathrm{m}^{2}$ of thermal energy per year and the payback time of these systems is over 8 years without any subsidies. Medium-scale solar systems have a big potential in Lithuania but it is recommended to install these systems for DHW production in buildings with district heating systems. However, the support from government and European Union for solar systems is still necessary [15-17].

Several studies show that despite the fact that evacuated tube and flat plate collectors are considered to be suitable for solar heating in Central European climates, the evacuated tube collectors does not reach the additional expected energy yield [18]. Flat plate collectors and evacuated tube collectors produce the same amount of energy from effective area during summer season in Lithuania, but it is much less expensive to use flat collectors in most cases $[19,20]$. The relation between installation costs and area of the flat plate solar collectors for each particular case can be estimated by using the relation presented in Figure 1 [21]. 


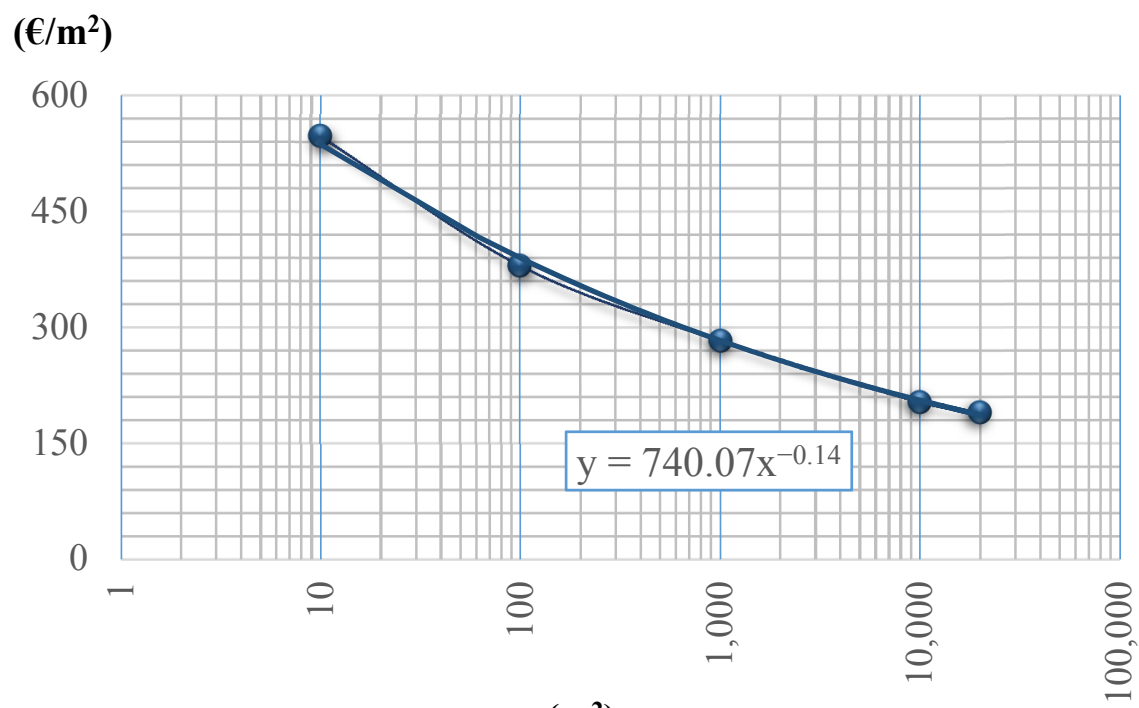

$\left(\mathbf{m}^{2}\right)$

Figure 1. Installation costs per $\mathrm{m}^{2}$ of different sizes of solar heat energy plants, including heat storage [21].

Heat output and cost of heat energy from medium and large solar arrays published by Danish governance is presented in the Table 1 [22]. Heat energy from large solar arrays are profitable in Denmark without subsidy versus the ex-tax price of fossil fuel imports, which is not a claim that many renewables can make.

Table 1. Solar heat cost according to the system size assuming that $1 \mathrm{~m}^{2}$ is rated at $700 \mathrm{~W}$ and produce $500 \mathrm{kWh} / \mathrm{yr}$ heat energy at suitable temperatures for DHW systems [22].

\begin{tabular}{|c|c|c|c|}
\hline \multicolumn{2}{|c|}{ Size of installed solar collector array } & \multirow{2}{*}{$\begin{array}{c}\text { Annual heat energy production } \\
\text { MWh }\end{array}$} & \multirow{2}{*}{$\begin{array}{c}\text { Cost of heat energy } \\
€ / \text { kWh, FOB } \\
\end{array}$} \\
\hline $\mathbf{m}^{2}$ & MW & & \\
\hline 500 & 0.35 & 250 & 0.09 \\
\hline 1000 & 0.70 & 500 & 0.07 \\
\hline 5000 & 3.50 & 2500 & 0.05 \\
\hline 10000 & 7.00 & 5000 & 0.03 \\
\hline 20000 & 14.00 & 10000 & 0.02 \\
\hline
\end{tabular}

There are several medium-scale SHW systems installed in Lithuania, varying from 60 to $166 \mathrm{~m}^{2}$ of total solar panel area. Most of these systems were installed in the past few years in multifamily or public buildings as well as industrial facilities, but the energy accounting monitoring systems in these buildings were usually not installed. The oldest still operational medium-scale SHW system was installed in 2002 in the "Žibute”" childrens sanatorium which is located at Kačerginè, Lithuania (flat plate collectors - $\left.77 \mathrm{~m}^{2}\right)[23,24]$.

The aim of this paper is to analyse three different operational SHW systems in Lithuania from the perspective of energy production and economic benefit as well as to outline the differences of their actual performance compared to the numerical simulation results. 


\section{Results}

\subsection{Energy Production Data}

Global specific irradiation onto an inclined surface (Kaunas), amount of energy produced and monthly efficiency of systems "A", "B" and "C" were analysed in this study. Performance parameters were calculated for a standard year and compared to the measured heat energy production. The results of the analysis are presented in Table 2.

Table 2. Measured and estimated heat energy production of solar collectors systems.

\begin{tabular}{cccccc}
\hline \multirow{2}{*}{ SHW system } & \multicolumn{2}{c}{$\begin{array}{c}\text { Measured annual energy } \\
\text { production (2013) }\end{array}$} & & \multicolumn{2}{c}{$\begin{array}{c}\text { Theoretical annual energy production } \\
\text { (T*SOL Pro 5.0, standard year) }\end{array}$} \\
\cline { 2 - 3 } \cline { 5 - 6 } & $\mathbf{k W h}$ & $\mathbf{k W h} / \mathbf{m}^{\mathbf{2}}$ absorber & & $\mathbf{k W h}$ & $\mathbf{k W h} / \mathbf{m}^{2}$ absorber \\
\hline "A" & 63630 & $411^{*}$ & & 68621 & 443 \\
"B" & 51680 & 488 & & 46568 & 439 \\
"C" & 24700 & 343 & & 25335 & 352 \\
\hline
\end{tabular}

* System "A" was not in operation for three weeks during August, 2013.

Measured annual efficiency of the analysed SHW systems reached up to $44 \%$ (system "B"), $39 \%$ (system " $A$ ") and $24 \%$ (system " $C$ "). The measured values of global irradiation in Kaunas and the amount of energy produced in the systems " $A$ ", " $B$ " and " $C$ " per month is presented in Figure 2.

The gap between measured and modelled data of heat energy produced by SHW systems was approx. $11 \%$ in the analysed cases. This can be caused by differences in actual solar irradiation compared to the standard average data. Total global annual irradiation on a horizontal area in 2013 in Kaunas city was $1089 \mathrm{kWh}$, which was higher than the average value used in the simulation software (984.9 $\mathrm{kWh}$ ). Therefore, there is approx. $10 \%$ difference between the simulated and actual solar irradiation.

However, it can be observed from Table 2 that system " $A$ " and " $C$ " produced less energy compared to the theoretical values obtained by the "T*SOL 5.0 Pro" software, yet system " $\mathrm{A}$ " was not in operation during almost all the month of August. On the other hand, the actual heat production can be affected by surface pollution of the solar collectors, technical flaws in the systems' installation as well as other factors which were not considered in the simulation.

Results of the simulation with "T*SOL 5.0 Pro" software showed that the analysed medium-scale solar systems in Lithuania should reduce GHG emissions by $142 \mathrm{~kg} \mathrm{CO} / \mathrm{m}^{2}$ absorber/year. As it can be observed from Figure 2, the solar thermal energy output from the system " $\mathrm{C}$ " is equal to zero during January, February and March. It was related to the fact that the heat is not supplied into the district heating network in cases when water temperature in the solar system is lower compared to the water temperature in the return pipe of the district heating network. On the other hand, heat energy was produced all year round by systems " $\mathrm{A}$ " and "B". 


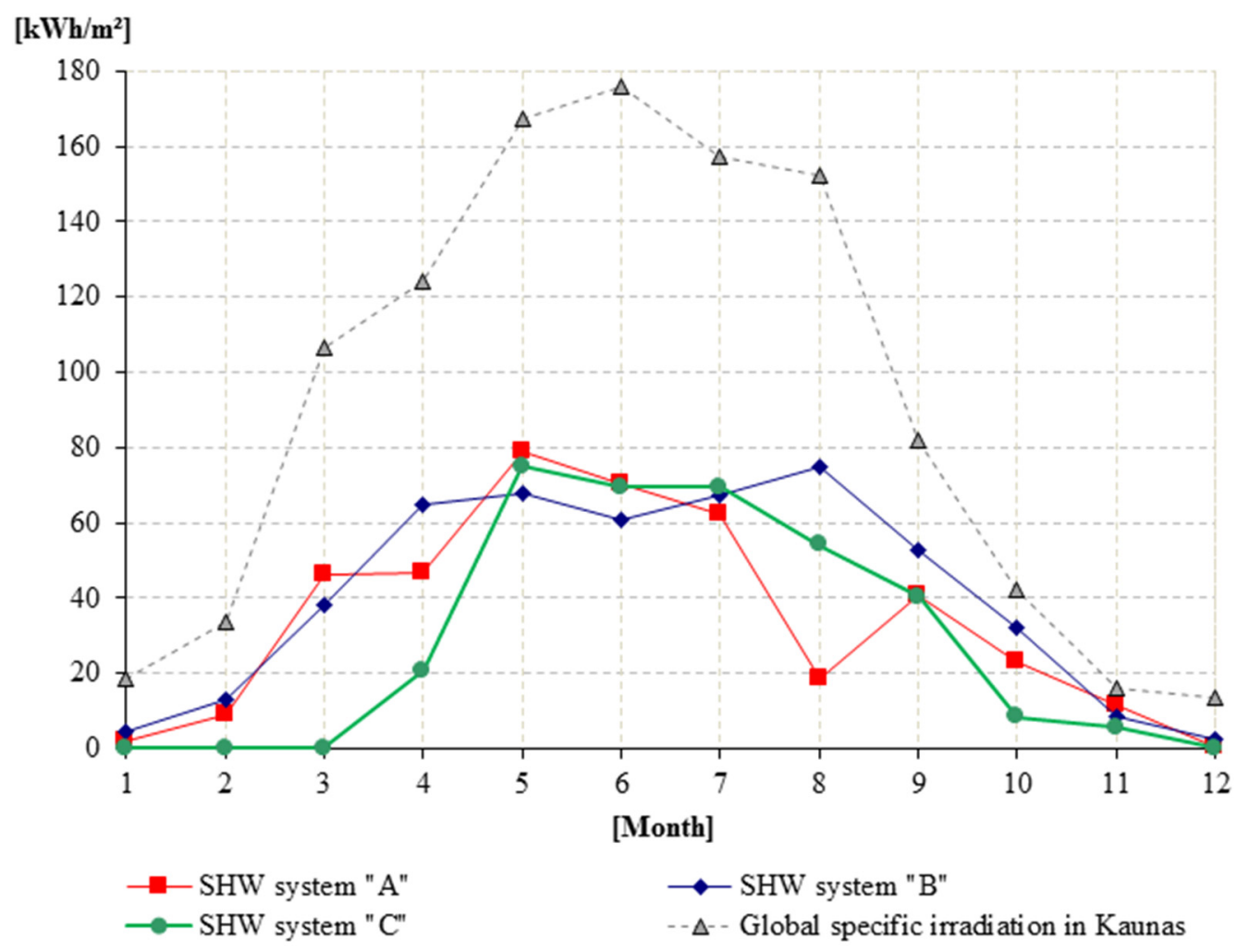

Figure 2. Amount of energy produced in the analysed systems $\left(\mathrm{kWh} / \mathrm{m}^{2}\right.$ absorber $)$ per month and measured global irradiation in Kaunas (2013).

\subsection{Financial Analysis of the Projects}

Financial analysis was performed for the systems " $\mathrm{A}$ " and "B". Due to the fact that the system "C" was upgraded several times, there's a lack of data on investments for this system. Therefore, this system is included in the solar energy production analysis, but it was excluded from the financial analysis. Investments and maintenance costs $\left(€ / \mathrm{m}^{2}\right)$ are presented in Table 3.

The calculated economical values includes Nominal Present Value (NPV) and Internal Rate of Return (IRR). These values are common financial indicators to determine the projects' viability and were calculated by the Equations 1 and 2:

$$
\mathrm{NPV}=-\mathrm{C}_{0}+\sum_{\mathrm{i}=1}^{\mathrm{T}} \frac{\mathrm{C}_{\mathrm{i}}}{(1+\mathrm{r})^{\mathrm{i}}}
$$

where:

$\mathrm{C}_{0}$ - initial investment, $€$;

$\mathrm{C}$ i-cash flow, $€$;

$\mathrm{r}$ - discount rate, $\%$;

$\mathrm{T}$ - time period, years.

$$
\mathrm{IRR}=\mathrm{r}_{\mathrm{a}}+\frac{\mathrm{NPV}_{\mathrm{a}}}{\mathrm{NPV}_{\mathrm{a}}-\mathrm{NPV}_{\mathrm{b}}} \cdot\left(\mathrm{r}_{\mathrm{b}}-\mathrm{r}_{\mathrm{a}}\right)
$$


where:

$\mathrm{r}_{\mathrm{a}}$-lower discount rate chosen (approximated), \%;

$\mathrm{rb}$-higher discount rate chosen (approximated), \%;

$\mathrm{NPV}_{\mathrm{a}}-\mathrm{NPV}$ at $\mathrm{r}_{\mathrm{a}}$ value $[€]$;

$\mathrm{NPV}_{\mathrm{b}}-\mathrm{NPV}$ at $\mathrm{rb}$ value [€].

It is mandatory to consider all financial parameters of an investment to outline the actual financial benefits of utilizing solar energy compared to conventional source of energy. In this study the assumption was made that the entire cost of the SHW system is covered during the installation. The life-span of the SHW system is considered to be 20 years. Parameters used for financial assessment of the system "A" and system "B" are presented in Table 3.

Table 3. Parameters used for financial assessment of SHW systems "A" and "B".

\begin{tabular}{ccc}
\hline SHW system & "A" & "B" \\
\hline Project lifetime, year & 20 & 20 \\
Index for energy prices, \%/year & 2.5 & 2.5 \\
Discount rate, $\%$ & 5.0 & 5.0 \\
Energy production, MWh/20 years & 1372 & 931 \\
Costs of propylenglycol replacement, $€ / 20$ years & 1600 & 960 \\
Costs of electricity for pumping, $€ / 20$ years & 5737 & 3893 \\
Loan (annuity), thousand $€ / 20$ years & 12.43 & 54.78 \\
Interest of loan (3\% for long-term projects), thousand $€ / 20$ years & 42.81 & 18.86 \\
\hline
\end{tabular}

In the case when all expenses through the 20 years are calculated, the performance of system " $\mathrm{B}$ " is higher compared to the system "A". The cost of solar heat energy utilized by the system "B" is approximately $84 € / \mathrm{MWh}$, which is much lower compared to the system " $A$ " (127€/MWh).

To determine the financial profitability of both systems, economic indicators NPV and IRR were calculated and the results are presented in Table 4. Financial estimations presented in the Table 4 were performed by using the average comparative price of electricity (Figure 3) and average district heat energy price for Lithuania as an alternative to the SHW systems "A" and "B".

The financial analysis showed that heat energy generated by medium-scale scale solar thermal systems is not competitive in comparison with energy produced by the Lithuanian DH network. The IRR calculation results showed a negative value for the system "A" and zero value for the system " $B$ ". Both projects can be defined as profitable in the other scenario, where electrical energy was used as an alternative to the energy produced by SHW systems.

Table 4. Estimated financial indicators for the analysed SHW projects.

\begin{tabular}{cccccc}
\hline \multirow{2}{*}{$\begin{array}{c}\text { Financial } \\
\text { indicator }\end{array}$} & \multicolumn{2}{c}{$\begin{array}{c}\text { Financial values in } \\
\text { competition with DH energy }\end{array}$} & & \multicolumn{2}{c}{$\begin{array}{c}\text { Financial values in } \\
\text { competition with electrical energy }\end{array}$} \\
\cline { 2 - 3 } & System "A" & System "B" & & System "A" & System "B" \\
\hline Investment, $€ / \mathrm{m}^{2}$ & 749 & 516 & & 749 & 516 \\
$\mathrm{NPV}, €$ & 45559 & 30473 & & 84290 & 52814 \\
$\mathrm{IRR}, \%$ & -2.8 & 0.0 & & 1.5 & 4.6 \\
\hline
\end{tabular}




\section{[€/MWh]}

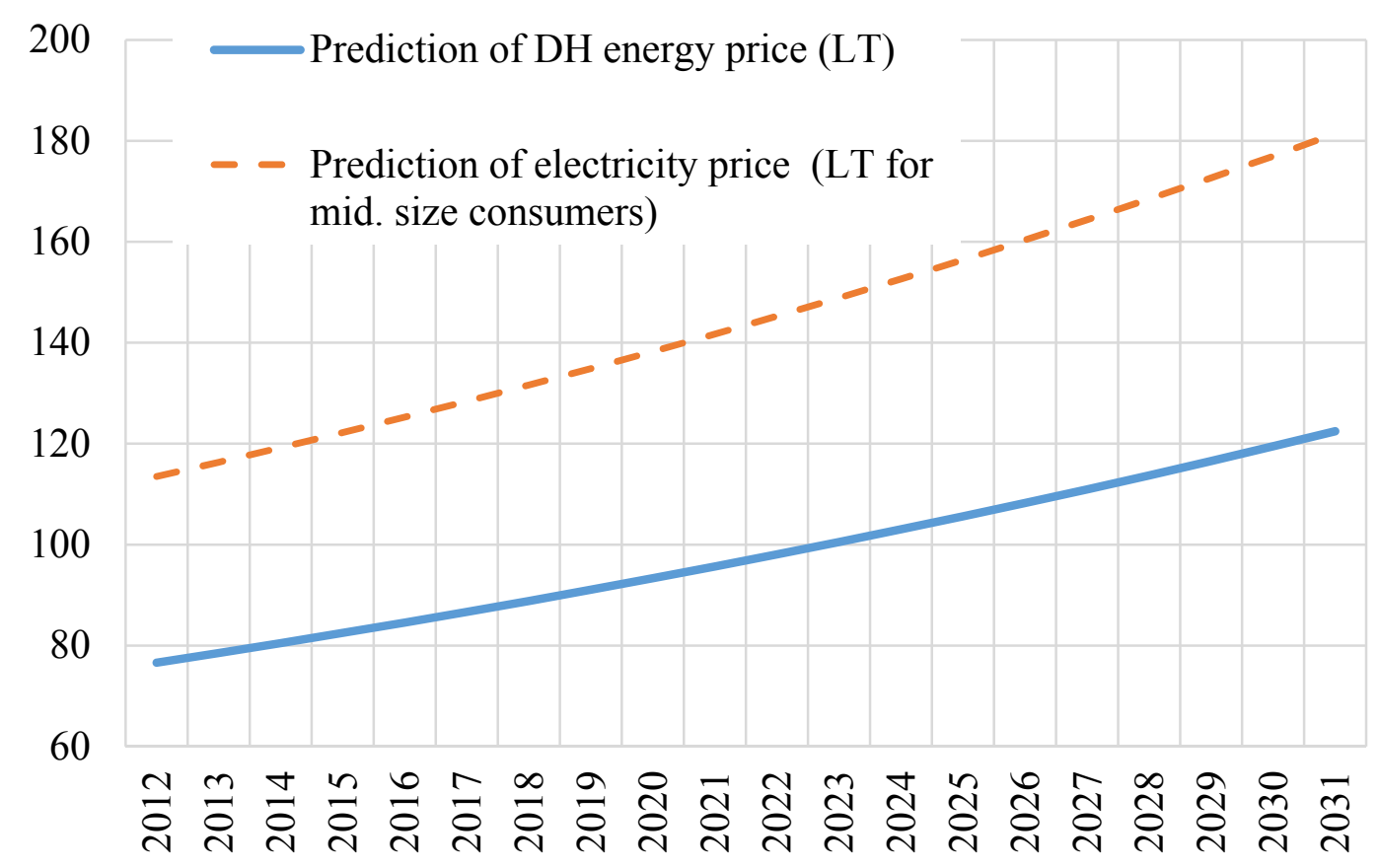

Figure 3. Prediction of district heating (DH) and electrical energy prices in Lithuania (according to historical average oil price growth-2.5\%/year since 1960).

\subsection{Grant Requirement for Solar Thermal Systems Profitability}

The review of today's World solar thermal market and performing solar thermal systems shows that most projects were implemented with governmental grants (Ranking List of European Large Scale Solar Heating Plants). Installation of almost all renewable energy generators have been supported by subsidy schemes which led to reduced investments, lower taxes etc. The Environmental Investment Fund (LEIF) subsidy program is responsible for supporting low GHG emission projects and the scale of the support for this type of investment projects is determined by the reduction of $\mathrm{CO}_{2}$ emissions.

Estimation of grant requirement for middle size SHW systems profitability in Lithuania was analysed in this study. Average DH heat energy price for Lithuania was used for the calculation of potential savings and the results of the analysis are presented in Figure 4.

IRR calculations revealed system " $B$ " to be more economically effective than system "A". The grant covering $35 \%\left(\sim 262 € / \mathrm{m}^{2}\right)$ of the investment costs in the case of the system " $\mathrm{B}$ " makes the project fully profitable $(\mathrm{IRR}=5.0 \%)$. 


\section{NPV \\ $[\mathbf{x 1 0 0 0} €]$}

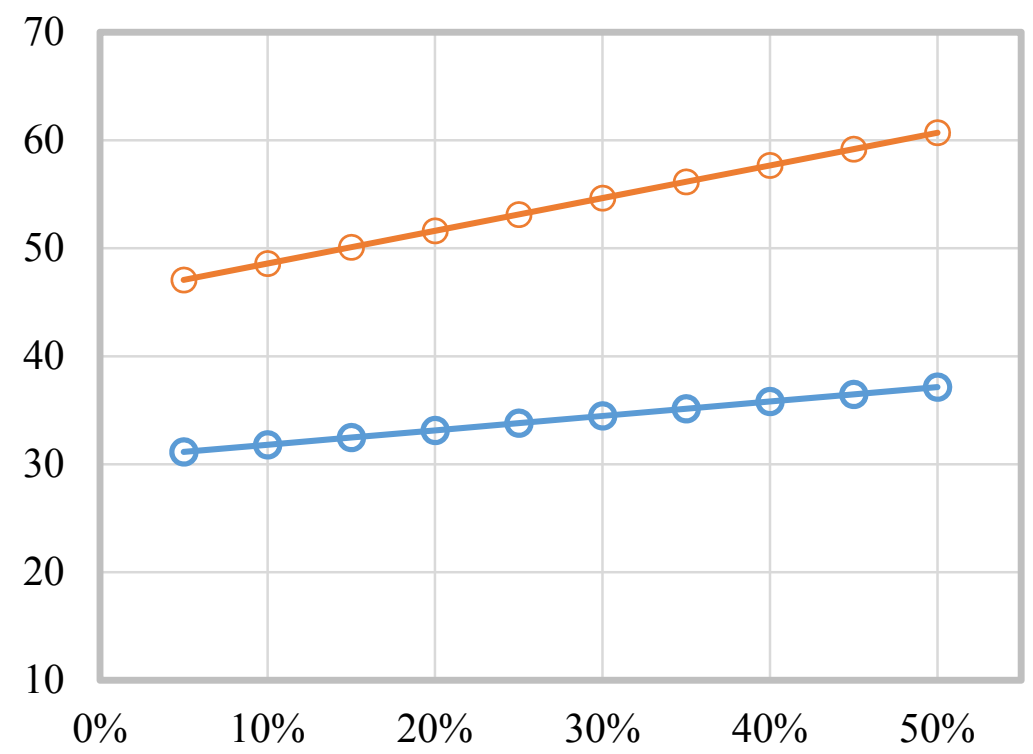

Grant for investment, [\%]

$\odot$ SHW System "A" $\quad \bullet-$ SHW System "B"

\section{IRR [\%]}

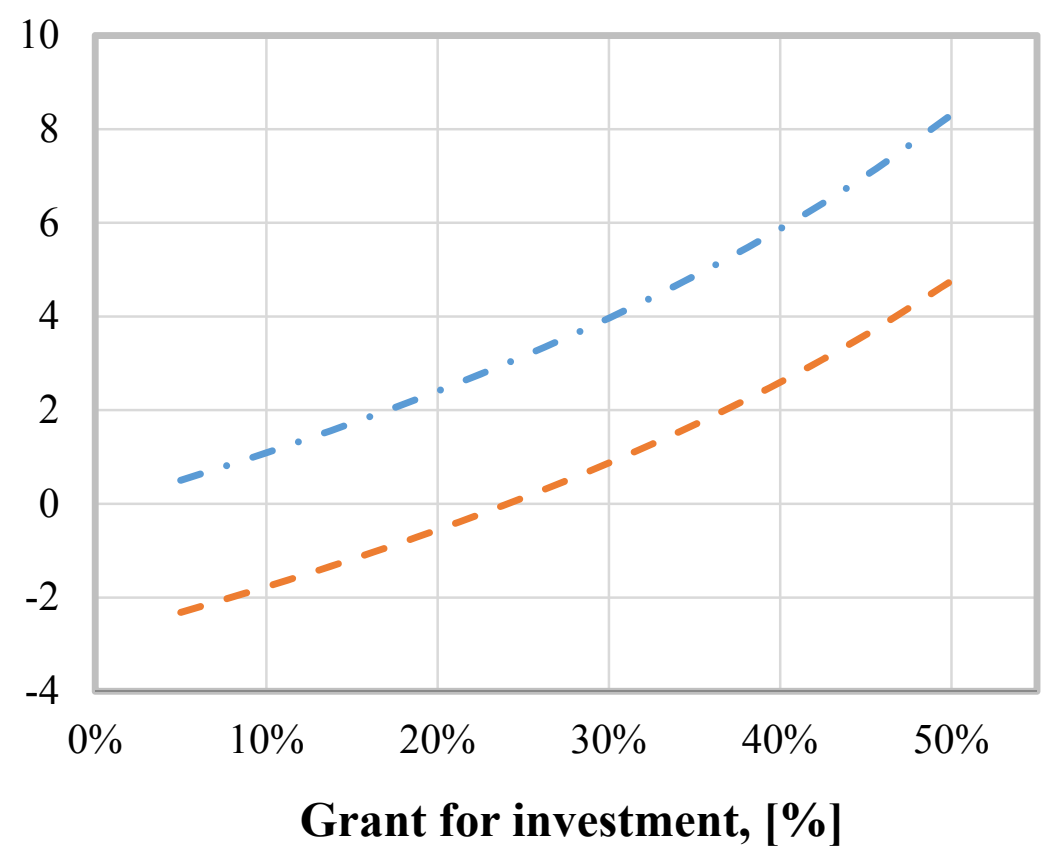

_ - SHW System "A" - - - SHW System "B"

Figure 4. Influence of the grant covering part of the investment costs on Nominal Present Value (NPV) and Internal Rate of Return (IRR) of the SHW systems "A" and "B". 


\section{Methodology}

In this work three different medium-scale solar thermal systems in Lithuania were evaluated. All of these systems are in operation from 2011 and are equipped with heat meters and monitoring systems.

- System " $A$ " is installed in the swimming pool building in Anykščiai (55 $\left.32^{\prime} 0^{\prime \prime} \mathrm{N} / 25^{\circ} 6^{\prime} 0^{\prime \prime} \mathrm{E}\right)$ and the solar energy is used for hot water heating as well as swimming pool heating. The system consists of 65 flat type solar collectors $\left(155 \mathrm{~m}^{2}\right)$ with $45^{\circ}$ inclination angle to the horizon and $10^{\circ}$ angle to the East. The heat is stored in five hot storage tanks of $1 \mathrm{~m}^{3}$ and the power of the heat exchanger used for the swimming pool of $600 \mathrm{~m}^{3}$ is $297 \mathrm{~kW}$. Daily hot water consumption in this building varies in the range of $4 \mathrm{~m}^{3} \pm 10 \%$.

- System "B" is installed in the Kruonis Pumped Storage Plant office building $\left(54^{\circ} 45^{\prime} 18.5^{\prime \prime} \mathrm{N} / 24^{\circ} 14^{\prime} 5.12^{\prime \prime} \mathrm{E}\right)$ and was designed for DHW heating. The system consists of 40 flat type solar collectors $\left(106 \mathrm{~m}^{2}\right)$ with $45^{\circ}$ inclination angle to the horizon, orientated directly to the South. Hot water is stored in three storage tanks of $4.1 \mathrm{~m}^{3}$. Daily hot water consumption in this building varies in the range of $5 \mathrm{~m}^{3} \pm 20 \%$ during work days and around $2 \mathrm{~m}^{3}$ during weekends.

- System "C" is installed as a part of the district heating system in Dūkštas (54 $50^{\prime} 0^{\prime \prime} \mathrm{N} / 24^{\circ} 58^{\prime} 0^{\prime}$ " E) and was initially used for hot water heating. The system was rebuilt in 2012 and is currently used for preheating the return water in the district heating network. The system consists of 36 "U-pipe" evacuated tube collectors $\left(82 \mathrm{~m}^{2}\right)$ with $45^{\circ}$ inclination angle to horizon, orientated directly to the South. Primary investments were 100.8 thousand $€$, however, the system was upgraded few times due to improper operation and the total investment is unknown.

Systems "A" and "B" represents the typical solar thermal installations in Lithuania. System " $C$ " is quite unique and it is the only installation used for district heating in the country. The summary of technical and economical characteristics of the above described systems are presented in Table 5.

Table 5. Technical and economical characteristics of the analysed systems.

\begin{tabular}{|c|c|c|c|}
\hline SHW system & "A" & "B" & "C" \\
\hline Type of solar collectors & Flat plate & Flat plate & Evacuated tube \\
\hline Total absorber area- $-\mathrm{A}_{\text {absorber, }} \mathrm{m}^{2}$ & 155 & 106 & 72 \\
\hline Total gross area- $\mathrm{A}_{\text {gross }}, \mathrm{m}^{2}$ & 166 & 114 & 82 \\
\hline Optical efficiency of collector $-\eta_{0}$ & 0.80 & 0.78 & 0.64 \\
\hline Linear heat transfer coefficient $-\mathrm{k}_{1}, \mathrm{~W} / \mathrm{m}^{2} \cdot \mathrm{K}^{2}$ & 3.872 & 3.545 & 0.885 \\
\hline Square heat transfer coefficient $-\mathrm{k}_{2}, \mathrm{~W} / \mathrm{m}^{2} \cdot \mathrm{K}^{2}$ & 0.014 & 0.011 & 0.001 \\
\hline Total investment $-\mathrm{I}_{\text {total }}$, thousand $€$ & 124.3 & 54.8 & $\mathrm{n} / \mathrm{a}$ \\
\hline Investment per $1 \mathrm{~m}^{2}$ absorber area- $-\mathrm{I}_{\text {per } \mathrm{m}^{2} \text { absorber, }} €$ & 749 & 516 & $\mathrm{n} / \mathrm{a}$ \\
\hline
\end{tabular}

All of the analysed systems have individual operational features that impact their produced energy amounts. System "B" has performed continuously from the start of the exploitation. System "A" was stopped for three weeks in August of 2013 during pool renovation work. The performance of system " $\mathrm{C}$ " was interrupted for a few days due to system upgrades.

The measured performance of the existing systems "A", "B" and "C" was compared to the theoretical values obtained by means of the "T*SOL Pro 5.0"(release 6) simulation software(Valentin Software 
$\mathrm{GmbH}$, Berlin, Germany). This simulation tool allows dynamic calculation of the annual solar energy yield as well as the design of SHW systems to achieve economic efficiency. All technical parameters of the existing systems such as inclination angle, orientation, energy demands and characteristics of the installed equipment were used as boundary conditions for the simulations.

\section{Conclusions and Discussion}

1. The results of the analysis presented in this study showed that medium scale SHW systems with solar flat plate and evacuated tube collectors can produce from 343 to $488 \mathrm{kWh} / \mathrm{m}^{2}$ heat energy in the case when the efficiency of these systems varies in the range of 24 to $44 \%$. Considering solar gain of $343 \mathrm{kWh} / \mathrm{m}^{2}$ per year and efficiency of $24 \%$, the district heating system from return pipe into a return pipe proved to be less effective compared to local SHW applications.

2. SHW systems with evacuated tube collectors does not reach the additional expected energy yield. In general, both collector types are suitable for SHW systems in Central European Climates. Moreover, it was estimated that the large SHW systems can produce from 323 to $465 \mathrm{kWh} / \mathrm{m}^{2}$ annually even at Nordic climate conditions.

3. The gap between measured and modelled data of heat energy produced by SHW systems was approx. $11 \%$ in the analysed cases. It can either be caused by differences in actual solar irradiation compared to the standard average data, or some peculiarities of the design and maintenance of the SHW systems.

4. The economic analysis showed that the IRR for analysed projects varies from $-7.1 \%$ to $4.6 \%$. Grant of 35\% investment makes the system "B" fully profitable (IRR $=5.0 \%)$.

There is still an insufficient number of medium-scale SHW systems in Lithuania to perform more detail statistical analysis and the number of installed evacuated tube medium-scale SHW systems is comparatively low. The payback time of SHW systems is too long to ensure stable growth of SHW applications without governmental grants. However, it is crucial to outline which systems should be subsidized and what maximum price of one $\mathrm{kW}$ of installed capacity can be applied.

\section{Author Contributions}

R.V. and A.J. performed data collection, numerical simulations and wrote the paper; R.J. performed financial analysis; V.K. and E.P. reviewed existing SHW systems.

\section{Conflicts of Interest}

The authors declare no conflict of interest.

\section{References}

1. Renewables Global Status Report. 2014. Available online: http://www.ren21.net/gsr (accessed on 5 February 2015).

2. Solar Thermal Markets in Europe-Trends and Market Statistics 2013. Available online: http://www.estif.org/statistics (accessed on 6 February 2015). 
3. Caouris, Y.G.; Rocco, P.; Zucchetti, M. Situation and perspectives for solar energy in Europe and a comparison with nuclear energy, after fukushima. Fresenius Environ. Bull. 2012, 21, 3301-3311.

4. Ayompe, L.M.; Duffy, A. Analysis of the thermal performance of a solar water heating system with flat plate collectors in a temperate climate. Appl. Thermal Eng. 2013, 58, 447-454.

5. Sakhrieh, A.; Al-Ghandoor, A. Experimental investigation of the performance of five types of solar collectors. Energy Convers. Manag. 2013, 65, 715-720.

6. Koroneos, C.J.; Nanaki, E.A. Life cycle environmental impact assessment of a solar water heater. J. Clean. Prod. 2012, 37, 154-161.

7. Hugo, A.; Zmeureanu, R. Residential solar-based seasonal thermal storage systems in cold climates: Building envelope and thermal storage. Energies 2012, 5, 3972-3985.

8. Hassine, I.B.; Eicker, U. Impact of load structure variation and solar thermal energy integration on an existing district heating network. Appl. Thermal Eng. 2013, 50, 1437-1446.

9. Lauterbach, C.; Schmitt, B.; Jordan, U.; Vajen, K. The potential of solar heat for industrial processes in Germany. Renew. Sustain. Energy Rev. 2012, 16, 5121-5130.

10. Augsten E. Norway: Solar Collectors Support District Heating. Available online: http://solarthermalworld.org/content/norway-solar-collectors-support-district-heating (accessed on 10 December 2014).

11. International Energy Agency. Country Report-Sweden: Status of Solar Heating/Cooling and Solar Buildings-2014. Available online: http:/www.iea-shc.org/country-report-sweden (accessed on 10 December 2014).

12. Solar Local district heating. Success Factors in Solar Districk Heating. Available online: http://www.solar-district-heating.eu/Portals/0/SDH-WP2-D2-1-SuccessFactors-Jan2011.pdf (accessed on 17 December 2014).

13. Denmark: Dronninglund Inaugurates 26 MWth Solar District Heating Plant. Available online: http://solarthermalworld.org/content/denmark-dronninglund-inaugurates-26-mwth-solar-districtheating-plant (accessed on 5 February 2015).

14. New Solar Technology Holds Big Potential. Available online: http://www.niras.com/ current-events/ news/2014/new-solar-technology-holds-big-potential.aspx (accessed on 5 February 2015).

15. Perednis, E.; Kavaliauskas, A.; Plikšienè, V. Karšto vandens ruošimo naudojant saulès kolektorius efektyvumo tyrimai. Energetika 2007, 1, 34-38.

16. Jonynas, R.; Valančius, R. The Comparison of Two Different Solar Collectors Systems. In Proceedings of the EuroSun 2010 the International Conference on Solar Heating, Cooling and Buildings, Graz, Austria, 28 September-1 October, 2010; pp. 1-8.

17. Adomavičius, V. Atsinaujinančiųų energijos išteklių naudojimo galimybès daugiabučiuose namuose. Lietuvos Taikomuju Moksly Akademijos Mokslo Darbai: Tarptautinis Inovacinis Taikomuju Mokslo Darbu Žurnalas = Off. J. Lithuanian Appl. Sci. Acad. 2010, 6, 107-122. Available online: http:/gjstudija.net/ltma/ltma-darbai/Str-VA-Daugiabuciai.pdf (accessed on 8 June 2015).

18. Trinkl, C.; Zörner, W.; Alt, C.; Stadler, C. Performance of Vacuum Tube and Flat Plate Collectors Concerning Domestic Hot Water Preparation and Room Heating. In Proceedings of the 2nd European Solar Thermal Energy Conference, Freiburg, Germany, 21-22 June 2005. 
19. Ambrulevičius, R. Exploitation Peculiarities of Sun Collectors Systems; LŽŪU ŽŪI Instituto ir LŽŪ Universiteto Mokslo Darbai: Raudondvaris, Lithuania, 2005; Volume 37, pp. 54-69.

20. Jonynas, R.; Valančius, R.; Šuksteris, V.; Perednis, E.; Mekas, G. Study of medium scale solar water heating plants in Lithuania. In Proceedings of the SES Solar World Congress, Kassel, Germany, 28 August-2 September, 2011; pp. 921-927.

21. Andrews, D. Background Report on EU-27 District Heating and Cooling Potentials, Barriers, Best Practice and Measures of Promotion. EC Joint Research Centre; Publications Office of the European Union: Luxembourg, Luxembourg, 2012. Available online: https://setis.ec.europa.eu/ system/files/JRCDistrictheatingandcooling.pdf (accessed on 8 February 2015).

22. Olivier, D.; Simmonds, A. Less Is More: Energy Security after Oil. Available online: http://www. sustainabilitywestmidlands.org.uk/wp-content/uploads/LessIsMoreEnergySecurityAfterOil.pdf (accessed on 8 February 2015).

23. Katinas, V.; Karbauskaitè, J.; Perednis, E.; Valančius, R. Efficiency analysis of combined biomass and solar energy in Lithuania. Clean Technol. Environ. Policy 2013, 15, 667-676.

24. Karbauskaitè, J.; Perednis, E. Kačerginès vaikų sanatorijos šilumos energijos vartojimo mažinimo galimybès. Energetika 2011, 57, 20-25.

(C) 2015 by the authors; licensee MDPI, Basel, Switzerland. This article is an open access article distributed under the terms and conditions of the Creative Commons Attribution license (http://creativecommons.org/licenses/by/4.0/). 